Abstracta Iranica

Revue bibliographique pour le domaine irano-aryen

Volume 34-35-36 | 2017

Comptes rendus des publications de 2011-2013

\title{
Denise Aigle. Sainteté et miracles. Deux saints fondateurs en Iran méridional (XI et XIV ${ }^{e} s$.)
}

\section{Pierre Lory}

\section{(2) OpenEdition}

1 Journals

\section{Édition électronique}

URL : http://journals.openedition.org/abstractairanica/41935

DOI : 10.4000/abstractairanica.41935

ISSN : 1961-960X

Éditeur :

CNRS (UMR 7528 Mondes iraniens et indiens), Éditions de l'IFRI

Référence électronique

Pierre Lory, "Denise Aigle. Sainteté et miracles. Deux saints fondateurs en Iran méridional (XIe et XIV $s$.) 》, Abstracta Iranica [En ligne], Volume 34-35-36 | 2017, document 2, mis en ligne le 30 décembre 2016, consulté le 02 octobre 2020. URL : http://journals.openedition.org/abstractairanica/41935; DOI : https://doi.org/10.4000/abstractairanica.41935

Ce document a été généré automatiquement le 2 octobre 2020.

Tous droits réservés 


\title{
Denise Aigle. Sainteté et miracles. Deux saints fondateurs en Iran méridional (XI et $\mathrm{XIV}^{e} \mathrm{~s}$.)
}

\author{
Pierre Lory
}

\section{RÉFÉRENCE}

Denise Aigle. « Sainteté et miracles. Deux saints fondateurs en Iran méridional $\left(\mathrm{XI}^{\mathrm{e}}\right.$ et $\mathrm{XIV}^{\mathrm{e}}$ s.) ». Oriente moderno, vol. 93, 2013, p. 79-100

1 L'article met en parallèle les deux biographies du ŠayH Abū Ishāa Kāzerūnī (m. 1033), et de son lointain successeur Amīn al-dīn Balyānī (m. 1345). Ces deux textes présentent des similarités, car il s'agit de récits de fondation, de renforcement d'une voie soufie dans la même ville de Kāzerūn. L'A. souligne plusieurs parallèles : les miracles ou jeu de rêves prémonitoires analogues, des allusions à la vie de Muhammad voire ses interventions oniriques, le récit de leurs décès fondant leur succession. Le jeu de miroir est cependant subtil : la biographie de Balyānī n'est pas un pur calque du premier, il cherche à trouver dans les récits sur le très prestigieux Kāzerūnī une source de légitimité.

\section{AUTEURS \\ PIERRE LORY \\ EPHE, Paris}

